\title{
THE SUSPENDED MATTER OF SEA WATER
}

\author{
By F. A. J. Armstrong and W. R. G. Atkins, F.R.S. \\ From the Plymouth Laboratory
}

Many chemical analyses have been made of the minor constituents of sea water which are utilized by plants and accordingly show definite seasonal variations. Analyses have also been made of the plankton strained out by fine-mesh silk nets. According to Harvey (1945) the finest bolting silk used, when wet and swollen, has a mesh of $42 \times 50 \mu$. This will let through the dwarf or nanoplankton, namely the smaller flagellates and diatoms, also bacteria, at least until the net is partially choked, as well as the finest clay particles, if any are still unprecipitated. Clay usually comes down close to the land, due to the action of the divalent magnesium and calcium ions of sea water as shown by Joly (1900).

\section{METHOD OF SAMPLING}

An attempt to measure the amount of these suspensions, living, dead and inanimate was made as follows. Carboys of sea water were filled at Station E I, about Io miles south-west of the Eddystone, in the English Channel, where the depth is $72-74 \mathrm{~m}$. The water was taken in a carefully scrubbed and washed oak bucket, poured in through a clean wooden funnel, under the eye of the authors. The water surface was always free from oil and care was taken that the rim of the bucket should not touch the side of the ship, which sometimes had dried mud remaining on it above the wetted portion.

The carboys used were well washed with hot lime-free tap water and finally with distilled water, as customary here, and closed with a clean cork sealed in position. It was found that some of the suspended matter adhered to the glass, so during filtration it was loosened with a brush, which was then well washed. After the first four samples we considered that the customary cleaning of the carboy was likely to leave some of this matter on the glass. So from June I948, inclusive, the carboys were cleaned with hot strong sulphuric acid in addition. The analyses for February to May 1948 show that this adherence of previous deposits gave results which were too high, but the matter removed was similar in composition to the usual suspension.

\section{Filtration and Determination of Dry MatTer}

The volume of sea water filtered varied, as some was used for other analyses, but lay between I 5 and 291 ., with a mean close to 22 . It was filtered through a Whatman No. 50 paper, II cm. diameter, the ash of which, $0.2 \mathrm{mg}$., was negligible. This was done on a Buchner funnel with the water pump. The first Io 1 . was always re-filtered. 
As a test of the efficiency of the filtration sea water collected 8 November I949 was first filtered as usual; 25.01 . gave $24.7 \mathrm{mg}$. or $990 \mathrm{mg} . / \mathrm{m}^{3}$ of incinerated matter. Then 22.01 . of the filtrate were filtered through ' Gradocol' membranes having an average pore diameter $\mathrm{I} \cdot 09 \mu$. As these became clogged four had to be used in succession. The washed residue and the filters were ignited and gave $0.9 \pm 0.2 \mathrm{mg}$, or $40 \mathrm{mg} . / \mathrm{m}^{3}$, of which gravimetric analysis showed that $60 \%$ was silica, and ferric oxide $13 \%$, found colorimetrically using 2-2'-dipyridyl.

Thus the filter-paper, with re-filtration as described, allowed about $4 \%$ of the matter to pass through, which was later collected on the membrane. The appearance and composition of the fine suspended matter on the membrane were similar to that on the paper. Examination in the Tyndall beam showed that there was still matter in suspension in sea water filtered in succession through 'Gradocol' membranes I.09, 0.6I and 0.2 $\mu$ A.P.D., but the amount must have been exceedingly small by weight.

After washing free from salts the residue was also washed with $20 \mathrm{ml}$. portions of acetone till colourless, and dried at $100^{\circ} \mathrm{C}$. The net weight is that of organic and inorganic matter, insoluble in water and acetone. But only occasionally was there enough on the paper to render this weighing worth while, as it is necessarily less accurate than that of the incinerated residue.

The paper was incinerated below red heat till carbonaceous matter was destroyed. The ratio of the organic matter to the inorganic and ash was 0.68 in July I948 and I.OI in February I949. In March, April and May I948 the imperfectly cleaned carboys gave respectively the ratios $0.9 \mathrm{I}, \mathrm{I} \cdot 82$ and $0.3 \mathrm{I}$, but the March and April samples were not filtered till $4 \frac{1}{2}$ and $3 \frac{1}{2}$ months after collection.

The values for July I 948 and February I 949 give the insoluble organic matter as $\mathrm{I} \cdot 77$ and $\mathrm{I} \cdot 62 \mathrm{~g}$. dry weight for a cubic metre of water at the surface. This is a direct determination, but may be low on account of the loss of soluble substances.

The July I948 ratio, 0.68 , is moreover low, as on this occasion the inorganic matter was enriched with calcium carbonate which constituted $70 \%$ instead of about $20 \%$. The high calcium content is probably due to high temperature and $\mathrm{pH}$ value, which combine to cause precipitation.

The incinerated dry matter is shown in the table as $\mathrm{mg} . / \mathrm{m} .{ }^{3}$ The constituents are shown both in $\mathrm{mg} . / \mathrm{m} .^{3}$ to afford a comparison with analyses of the salts in solution and in percentages, using the oxide formulae as customary in the analyses of clays in agricultural work and in the Challenger analyses.

\section{Gravimetric ANALysis of THE Residue}

Silica was determined by the loss of silicon tetrafluoride. The factor to correct to $\mathrm{Si}$ is 0.467 .

Iron was found by fusion of the residue with potassium hydrogen sulphate, followed by acid extraction, formation of the cupferron complex and its extrac- 
tion with chloroform. The solvent was removed and the complex destroyed with sulphuric acid and heat, followed by hydrogen peroxide, solution in acid and ammoniacal precipitation when just alkaline to methyl red. The precipitate was ignited and weighed as $\mathrm{Fe}_{2} \mathrm{O}_{3}$; the factor to convert to $\mathrm{Fe}$ is 0.700 .

Aluminium was precipitated in the aqueous solution after the cupferron extraction by addition of ammonium chloride and then hydroxide till just alkaline to methyl red. The precipitate was ignited and weighed as $\mathrm{Al}_{2} \mathrm{O}_{3}$. The factor to convert to $\mathrm{Al}$ is 0.529 .

The filtrate from the aluminium determination was freed from ammonium salts, organic matter if present being destroyed with hydrogen peroxide. Calcium was then precipitated as oxalate, and ignited and weighed as the carbonate. The factor to convert to $\mathrm{Ca}$ is 0.400 .

One determination of phosphorus was made on a duplicate carboy of 30 November 1948. In view of the acid extraction necessary later on this was filtered on a Jena grade 3 (medium porosity) sintered glass crucible. With refiltration of the first 101 . this proved efficient, and gave $2100 \mathrm{mg} . / \mathrm{m} \cdot{ }^{3}$ residue dried at $100^{\circ} \mathrm{C}$. Cold extraction with $0.28 \mathrm{~N}-\mathrm{H}_{2} \mathrm{SO}_{4}$ gave $3 . \mathrm{I} \mathrm{mg}$. $/ \mathrm{m} .{ }^{3}$, and hot extraction (in autoclave, Harvey, I948) gave a further $2 \cdot 2 \mathrm{mg}$. The residue when incinerated and extracted gave $0.2 \mathrm{mg}$., so total phosphorus in residue was $5.5 \mathrm{mg} . / \mathrm{m}^{3}$

Since the other carboy gave $950 \mathrm{mg}$. $/ \mathrm{m}^{3}{ }^{3}$ incinerated residue a further value for the organic/inorganic matter ratio is obtainable, namely $\mathrm{I} \cdot 2 \mathrm{I}$ and the insoluble organic matter is $1 \cdot 15 \mathrm{~g} . / \mathrm{m}^{3}$ The samples of water may not have been identical in the two carboys, but are likely to have been closely similar.

\section{Discussion OF RESULTS}

The results are given in Table I. Neglecting results from inadequately cleaned carboys the incinerated dry matter ranges from $2 \cdot 77$ to $0.45 \mathrm{~g}$. $/ \mathrm{m} .{ }^{3}$, namely parts per million, with silica as the main constituent in all but four cases. In one of these calcium carbonate, probably from the sea, constituted $70 \%$.

The silica may have three origins: silica as such from diatom tests, silica fairly pure from small sand grains and apparently buoyed up by organic matter, and silicates of aluminium and iron, namely clay, brought down by rivers.

Incinerated dry matter varied from I00 to I6; the silica from roo to 9; the iron oxide from 100 to 20 ; the aluminium oxide from 100 to 7 . The greatest variation in silica was, very strangely, between 8 and I7 August 1949, with 80 and $880 \mathrm{mg} . / \mathrm{m} .^{3}$ respectively. As against this Atkins (1926) found silica in solution at E I, O m., to vary from 240 to $40 \mathrm{mg}$. between 1923 and 1926 . It appears, therefore, that the silica in suspension must-from the aluminium figures-be largely present as silicate and capable of enriching water depleted by diatom growth by slow solution. There is, however, no sign of any regular seasonal change in the silicate. The figures appear quite fortuitous. Nor do 
Table I. Weight of Suspended Matter in i $M .^{3}$ of Sea Water, Shown as Inorganic Matter and Ash, AFTER INCINERATION, IN MILligrams, EQUivalent to PARTS PER ThOUSAND Million

The major constituents are shown, also the percentage composition. The years are 1948, above, and 1949 .

\begin{tabular}{|c|c|c|c|c|c|c|c|c|c|c|c|c|}
\hline \multirow[b]{2}{*}{ Date } & \multicolumn{5}{|c|}{ Weights (mg.) } & \multicolumn{5}{|c|}{ Composition (\%) } & \multirow[b]{2}{*}{${ }^{\circ} \mathrm{C}$. } & \multirow{2}{*}{$\underset{(\%)}{\text { Salinity }}$} \\
\hline & Total & $\mathrm{SiO}_{2}$ & $\mathrm{Fe}_{2} \mathrm{O}_{3}$ & $\mathrm{Al}_{2} \mathrm{O}_{3}$ & $\mathrm{CaCO}_{3}$ & Total & $\mathrm{SiO}_{2}$ & $\mathrm{Fe}_{2} \mathrm{O}_{3}$ & $\mathrm{Al}_{2} \mathrm{O}_{3}$ & $\mathrm{CaCO}_{3}$ & & \\
\hline II Feb. & $\mathrm{I}, 060^{\star}$ & 465 & 96 & $8 I$ & 250 & 85 & 44 & 9 & 8 & 24 & IO. I & $35 \cdot 27$ \\
\hline Io Mar. & $6,770^{\star}$ & 3,700 & 740 & 1,300 & 630 & 95 & 55 & II & 20 & 9 & $9 \cdot 3$ & $35 \cdot 35$ \\
\hline Io May & $15,300^{\star}$ & 7,900 & - & 1,800 & 2,400 & 80 & 52 & - & 12 & I6 & 12.4 & $35 \cdot 46$ \\
\hline 9 June & $\mathrm{I}, \mathrm{I} 40$ & 520 & 130 & 70 & 200 & 89 & 54 & II & 6 & I8 & $12 \cdot 6$ & $35 \cdot 34$ \\
\hline I5 July & 2,770 & 700 & 86 & $<20$ & I,900 & 99 & 25 & 3 & $<$ I & 70 & 14.7 & $35 \cdot 34$ \\
\hline I6 Äug. & 890 & 380 & 130 & 50 & 160 & 82 & 43 & I5 & 6 & I8 & 15.4 & $35 \cdot 34$ \\
\hline 4 Oct. & 490 & 220 & 60 & 60 & 90 & 88 & 44 & 12 & 13 & 19 & 14.7 & $35 \cdot 37$ \\
\hline 5 Jan. & 760 & 160 & 160 & 130 & 190 & 84 & $2 I$ & $2 I$ & I7 & 25 & II $\cdot 2$ & $35 \cdot 35$ \\
\hline I Feb. & 1,600 & 420 & 250 & 160 & 310 & $7 \mathrm{I}$ & 26 & I5 & Io & 19 & $10 \cdot 2$ & $35 \cdot 27$ \\
\hline I Mar. & 740 & 160 & 130 & 80 & 90 & 62 & $2 I$ & 17 & II & 13 & IO. I & $35 \cdot 3^{8}$ \\
\hline I3 Apr. & 800 & 300 & roo & 90 & 190 & 84 & 37 & 13 & II & 23 & 9.9 & $35 \cdot 27$ \\
\hline 9 May & 800 & 250 & I80 & 80 & IIO & 77 & $3 I$ & 23 & IO & 13 & II 5 & $35 \cdot 32$ \\
\hline 9 June & 1,360 & 710 & IIO & I5O & 250 & 89 & 52 & 8 & II & I 8 & 13.9 & $35 \cdot 30$ \\
\hline 8 July & I,880 & 770 & 300 & 270 & 310 & 88 & $4 \mathrm{I}$ & I6 & I4 & 17 & 16.5 & $35 \cdot 4 \mathrm{I}$ \\
\hline 8 Aug. & 450 & 80 & 120 & 70 & Iro & 89 & I8 & 28 & 16 & 27 & 15.3 & $35 \cdot 43$ \\
\hline I7 Aug. & 2,020 & 880 & 260 & 160 & 490 & 89 & 44 & 13 & 8 & 24 & $16 \cdot 0$ & \\
\hline 8 Nov. & I,I90 & 520 & 210 & I90 & 310 & 103 & 44 & I7 & I6 & 26 & 14.0 & $35 \cdot 26$ \\
\hline
\end{tabular}


delays in the filtration of the carboys appear to cause any serious error, for filtration of the 8 August sample was begun on I6 August and that of I7 August on 20 August.

On the whole, the aluminium values appear to be low in the summer, giving the impression that it might be the more soluble. The amount of iron present in suspension was far more than that found in solution by Cooper (I935). Atkins (I945) showed that the reduction in silica in solution due to diatom production was only about 10 \% of that which should have been found had all the phosphate used gone to diatom production. The present demonstration of another source of silicate does tend to lessen this discrepancy, but can hardly be accepted as adequate to account for the great difference. One is thus justified in thinking that the non-siliceous phytoplankton may be quite important quantitatively.

\section{SUMMARY}

Sea water collected at Station E I, surface, between June 1948, and November I949, contained suspended matter from 2.77 to $0.45 \mathrm{~g} . / \mathrm{m}^{3}$ (or parts per million) dried and ignited. A few determinations of insoluble organic matter gave $\mathrm{I} \cdot 77$ to $\mathrm{I} \cdot \mathrm{I} 5$ parts per million dry weight at $100^{\circ} \mathrm{C}$. The ignited residue contained from 55 to $17 \%$ silica, 28 to 3 of ferric oxide, 20 to under I of alumina and 70 (or excluding one high value 29) to 9 calcium carbonate. There was nothing in the records for temperature or salinity to suggest that the water mass had changed during the period of sampling.

The analyses reveal an unsuspectedly large amount of iron, compared with that found in solution. The ignited residue is rich in silicate, judging from the silica alumina ratio, but it is quite doubtful whether the additional supply of silicate available for diatoms is at all adequate to balance their requirements calculated on a phosphate utilization basis. It seems more probable that a considerable amount of the phosphate is available for non-siliceous phytoplankton.

\section{REFERENCES}

AtkINs, W. R. G., I926. Seasonal changes in the silica content of natural waters in relation to the phytoplankton. Fourn. Mar. Biol. Assoc., Vol. I4, pp. 89-99.

- 1945. Autotrophic flagellates as the major constituent of the oceanic phytoplankton. Nature, Vol. I56, p. 446.

Cooper, L. H. N., 1935. Iron in the sea and in marine plankton. Proc. Roy. Soc. London, B, vol. II8, pp. 419-38.

Harvey, W. H., I945. Recent Advances in the Chemistry and Biology of Sea Water. London.

- 1948. The estimation of phosphorus and of total phosphorus in sea waters. fourn. Mar. Biol. Assoc., Vol. 27, pp. 337-59.

Joly, J., I900. Du méchanisme intime de la sédimentation. Int. Geol. Congr., Paris. 